\title{
WEST GEORGIAN HONEY CATIONS
}

\section{Nona Abashidze $^{1}$, Maia Vanidze ${ }^{2}$, Maia Kharadze ${ }^{3}$, Indira Djaparidze ${ }^{4}$, Aleko Kalandia ${ }^{5}$}

\begin{abstract}
The present study was conducted to determine the content of four mineral elements in honeys originating from different regions of West Georgia. Sodium (Na), Potassium (K), Calcium (Ca), magnesium $(\mathrm{Mg})$, and Ammonium (NH4+) were analyzed by HPLC-Conductivity, column "Cation" $(3.9 x 150 \mathrm{~mm})$ solvent $0.1 \mathrm{mM}$ EDTA $3 \mathrm{mM} \mathrm{HNO}$, following the microwave digestion of the honey. High mineral contents were observed in the investigated honeys with $\mathrm{K}, \mathrm{Na}, \mathrm{Ca}$ and $\mathrm{Mg}$ being the most abundant elements with mean concentrations in Chestnut honey 5000-7000 ppm, 56-150 ppm, 40-230 ppm, 25130 ppm, respectively. In Lime (Tilia) honey - 2400-2600 ppm, 30-50 ppm, 160-180 ppm, 45-60 ppm, Acacia honey 300-500 ppm, 35-45 ppm, 85-95 ppm, 15-25 ppm, Field honey -750-930 ppm, 35-45 ppm, 75-130 ppm, 25-35 ppm, Spring polyflora honey - 630-650 ppm, 45-50 ppm, 280-300 ppm, 25-35 ppm, Autumn polyflora Honey - 2500-3000 ppm, 80-100 ppm, 250$300 \mathrm{ppm}, 80-100 \mathrm{ppm}$ respectively. The correlation dependence was between the content of cations in the honey and conductivity (Chestnut honey $1.4 \mu \mathrm{s} / \mathrm{cm}$, Lime (Tilia), honey $0.5 \mu \mathrm{s} / \mathrm{cm}$, Acacia honey $0.16 \mu \mathrm{s} / \mathrm{cm}$, Field honey $0.55 \mu \mathrm{s} / \mathrm{cm}$, Spring polyflora honey $1.2 \mu \mathrm{s} / \mathrm{cm}$, Autumn polyflora Honey $1.3 \mu \mathrm{s} / \mathrm{cm}$ )
\end{abstract}

UDC Classification: 547.1; DOI: http://dx.doi.org/10.12955/cbup.v6.1283

Keywords: Chestnut, Lime (Tilia), Acacia, Spring and Autumn Polyfloral Honey, cations, HPLC, conductivity

\section{Introduction}

Honey is not only a source of carbohydrate, it also contains many essential substances necessary for human health, including minerals, the composition of which significantly changes due to the geographical location of the collected honey, its botanical origin and the results of falsification. Special demand in the world market is enjoyed by monopoly honey. Different compounds are used as botanical markers to establish the naturalness of honey. Georgia, especially its western part, is historically known for its variety of honey productions. Among the dominant varieties are: chestnut honey, linden honey, acacia honey, as well as field and polyfloral honey. Determination of botanical origin of honey is quite difficult (Uršulin-Trstenjak et al., 2017, Bogdanov S. et al. 2007). Numerous studies have recently been carried out to establish chemical indices for determining the botanical origin of honey (Gonzralez-Miret et al., 2014, Gonzalez-Miret et al., 2005) among them there are a lot of studies in which the botanical origin and the mineral content are interconnected (Vanhanen L.P. et al., 2011, Wieczorek et al. 2014, Marcelo Enrique Conti et al. 2014, Marcelo Enrique Conti et al., 2007, Fernandez-Torres R.et al. 2005, Terrab A. et al. 2004).

Unfortunately, we do not have similar staff in our reality and conscientious beekeepers and consumers are not protected from falsification.

The purpose of our work was to study the cationic composition of honey of various botanical origins with a HPLC method and to establish a correlation between the chemical composition and botanical origin.

\section{Methods and materials}

Standards were obtained for Lithium hydroxide monohydrate $\left(\mathrm{Li}^{+}\right)$, Sodium chloride $\left(\mathrm{Na}^{+}\right)$, Ammonium chloride $\left.\mathrm{NH}^{+}\right)$, Potassium chloride $\left(\mathrm{K}^{+}\right)$, Magnesium nitrate hexahydrate $\left(\mathrm{Mg}^{2+}\right)$, Calcium nitrate tetrahydrate $\left(\mathrm{Ca}^{2+}\right)$, Strontium nitrate tetrahydrate $\left(\mathrm{Sr}^{2+}\right)$, Barium chloride dihydrate $\left(\mathrm{Ba}^{2+}\right)$ (Fisher Scientific), EDTA (Serva). Isocratic HPLC pump (Waters 1515), Detector Waters 432 (Conductivity) Column IC-Pak CationMD, Eluent $3 \mathrm{mM} \mathrm{HNO}_{3} / 0.1 \mathrm{mM}$ EDTA, Blancconductivity $1250 \pm 50 \mu \mathrm{S}$, Base Sensitivity $2000 \mu \mathrm{S}$, Integrator Sensitivity $\mu \mathrm{S}$, column temperature $35^{\circ} \mathrm{C}$, Polarity-negative.

\footnotetext{
${ }^{1}$ Batumi Shota Rustaveli State University, Faculty of Natural Sciences and Health Care, Department of Chemistry, Batumi, Georgia, abashidzenona09@gmail.com

${ }^{2}$ Batumi Shota Rustaveli State University, Faculty of Natural Sciences and Health Care, Department of Chemistry, Batumi, Georgia, vanidzemaia@gmail.com

${ }^{3}$ Batumi Shota Rustaveli State University, Faculty of Natural Sciences and Health Care, Department of Chemistry, Batumi, Georgia, maikharadze88@gmail.com

${ }^{4}$ Batumi Shota Rustaveli State University, Faculty of Natural Sciences and Health Care, Department of Chemistry, Batumi, Georgia, indira.djafaridze@gmail.com

${ }^{5}$ Batumi Shota Rustaveli State University, Faculty of Natural Sciences and Health Care, Department of Chemistry, Batumi, Georgia, aleko.kalandia@bsu.edu.ge
} 
Conductivity $\mathrm{mS} / \mathrm{cm}$ - Conductometer (Mettler Toledo) samplers added deionized water (1:5) (Chudzinska and Baralkiewicz, 2010, Yücel and Sultanoğlu, 2013)

The samples of Chestnut Honey were taken in places of intensive production of honey - in Adjara, Samegrelo, Imereti, Guria (in total 115 samples, among them the results were generalized for 17 samples (the samples fully complied with the standards of Euro regulations).

\section{Results and their review}

In Western Georgia Chestnut Honey is distinguished with potassium content. Its content in natural honey is approximately up to $5000 \mathrm{mg} / \mathrm{kg}$. Regions do not play a significant role in this regard. The honey, collected in the mountainous village located at $300 \mathrm{~m}$ above sea level, was particularly interesting. Potassium content in it exceeded $7000 \mathrm{mg} / \mathrm{kg}$. In all the samples of natural honey, the share of potassium in the total composition of cations is more than $90 \%$. The conductivity of the studied honey ranged from 1.41 to $1.96 \mathrm{~S} / \mathrm{cm}$. It is interesting to note, that there was established a certain correlation between the total composition of cations and the conductivity in Chestnut Honey. In natural honey this indicator ranges from 0.3 to 0.44 . The quantitative ratio of potassium to the total amount of cations and conductivity can be used as markers for the identification of naturalness of chestnut honey.

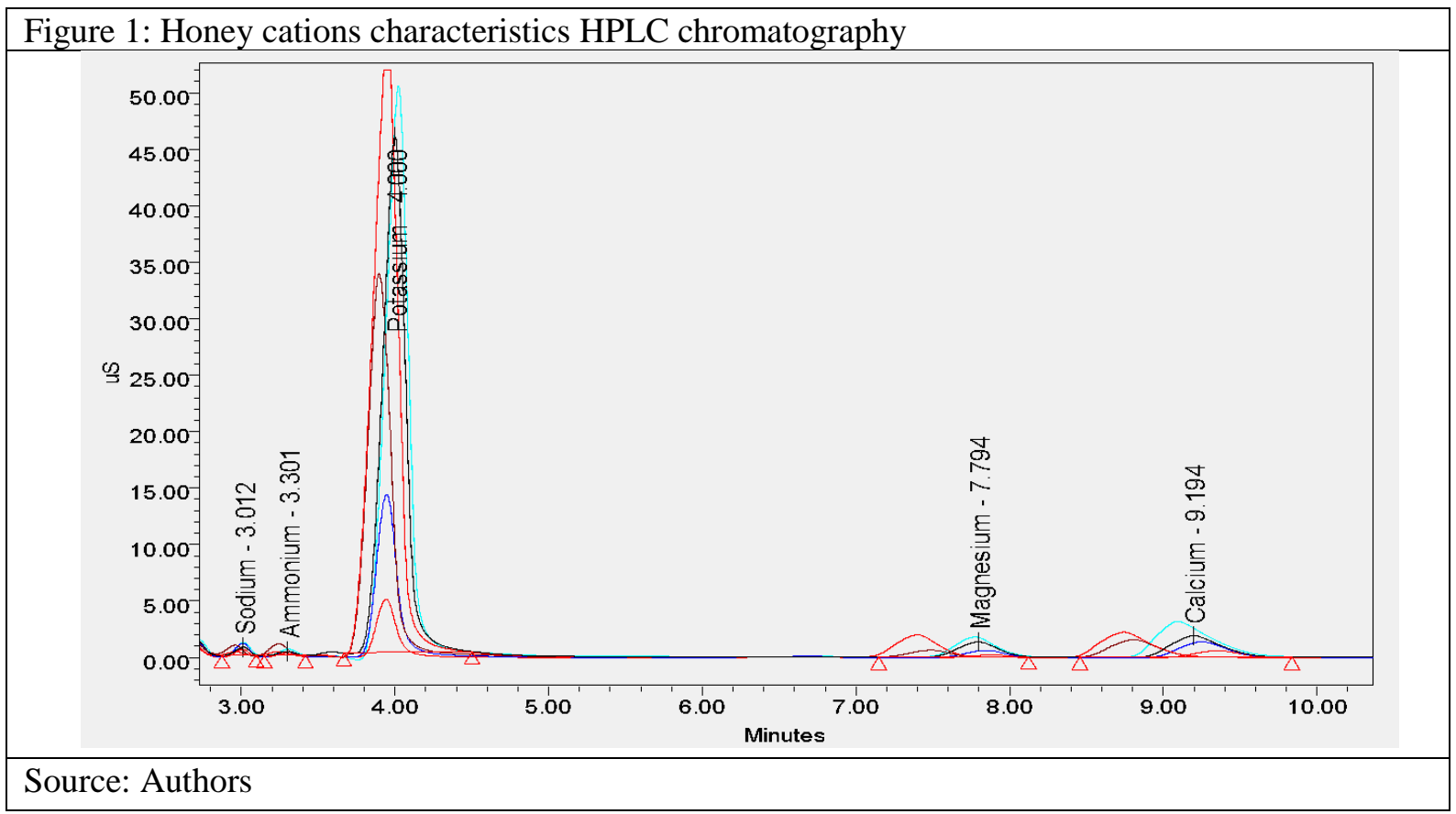

As the results have shown, the total content of cations in Chestnut honey isn't more than 8-9 \%. In most of the samples, the indicators of calcium are from $14 \mathrm{mg} / \mathrm{kg}$ to $500 \mathrm{mg} / \mathrm{kg}$, which is $0.33-7.2 \%$ of the total content of cations, while magnesium is from 51 to $130 \mathrm{mg} / \mathrm{kg}$, which is $0.88-1.95 \%$ of the total content of cations. As for the sodium, its content is from 26 to $140 \mathrm{mg} / \mathrm{kg}$, which is $0.45-2.1 \%$ of the total content of cations. The content of the ammonium varies quite a lot in a large range between 24 and 197 $\mathrm{mg} / \mathrm{kg}$ (Tables 1,2$)$.

In Lime (Tilia) honey potassium is the dominant-cation, with a quantitative content of minimum 2377 ppm and maximum of $2747 \mathrm{ppm}$. Its content significantly changes ( $\min 5167.94 \mathrm{ppm}$-max $6516.32 \mathrm{ppm}$ ) when the honey is collected with simultaneous flowering of chestnut and linden (Table 3). The content of total potassium cations is about $90 \%$. The content of potassium in the analyzed Tilia honey varies very strongly (min $1660.38 \mathrm{ppm}$, max $3444.5 \mathrm{ppm}$ ) (Table 3).

In the spring and autumn, honey is polyfloral, and the potassium content in it is quite high. The amount of the total potassium cations is at least $87.9 \%$. Among the other ions in the studied types of honey (in Chestnut honey as well), Ca2 + varies from 43.6 to $378 \mathrm{ppm}$, and $\mathrm{Mg}^{2+}$ is 29,8 to $94,1 \mathrm{ppm}$, that is 1.77 $8.44 \%$ of the total amount of cations. The content of $\mathrm{Na}^{+}$cations is $28.2-134.3 \mathrm{ppm}$, that is only about 1.12 to $2.9 \%$ of cation total content (Table 4 ). The conductivity is not less than $0.81 \mathrm{~s} / \mathrm{cm}$ and the total amount of cations (\%) and conductivity is from 0.23 to 0.41 . 
CBU INTERNATIONAL CONFERENCE ON INNOVATIONS IN SCIENCE AND EDUCATION

\begin{tabular}{|c|c|c|c|c|c|c|c|c|c|c|}
\hline \multicolumn{2}{|c|}{ Table 1: Chestnut honey Cations, Conductivity and Ratio } \\
\hline Name & Samplers & $\begin{array}{c}\mathrm{Na}^{+} \\
\mathrm{ppm}\end{array}$ & $\begin{array}{c}\mathrm{NH}^{+} \\
\mathrm{ppm}\end{array}$ & $\begin{array}{c}\mathrm{K}^{+} \\
\mathrm{ppm}\end{array}$ & $\begin{array}{c}\mathrm{Mg}^{+} \\
\mathrm{ppm}\end{array}$ & $\begin{array}{c}\mathrm{Ca}^{+} \\
\mathrm{ppm}\end{array}$ & $\begin{array}{c}\text { Total } \\
\mathrm{ppm}\end{array}$ & $\begin{array}{c}\text { Total } \\
\text { catio } \\
\mathrm{ns} \%\end{array}$ & $\begin{array}{c}\text { Cond } \\
\text { s/cm }\end{array}$ & $\begin{array}{c}\text { Ration } \\
\text { Cation } \\
\text { /conduct }\end{array}$ \\
\hline H 9 & $\begin{array}{c}\text { Chestnut honey } \\
\text { Mengrelia min }\end{array}$ & 86.34 & 54.32 & 5050.06 & 74.76 & $13-44$ & 5278.92 & 0.53 & 1.41 & 0.37 \\
\hline H 21 & $\begin{array}{c}\text { Chestnut honey } \\
\text { Mengrelia max }\end{array}$ & 63.26 & 43.84 & 5839.40 & 65.82 & 247.14 & 6259.46 & 0.63 & 1.75 & 0.36 \\
\hline H 18 & $\begin{array}{c}\text { Chestnut honey } \\
\text { Guria max }\end{array}$ & 112.18 & 52.28 & 5154.04 & 58.18 & 267.66 & 5644.34 & 0.56 & 1.41 & 0.40 \\
\hline H 17 & $\begin{array}{c}\text { Chestnut honey } \\
\text { Guria min }\end{array}$ & 112.14 & 73.50 & 6840.42 & 110.32 & 307.34 & 7443.72 & 0.74 & 1.71 & 0.44 \\
\hline H 24 & $\begin{array}{c}\text { Chestnut honey } \\
\text { Imeretia min }\end{array}$ & 122.82 & 51.78 & 5401.38 & 51.22 & 220.74 & 5847.94 & 0.58 & 1.67 & 0.35 \\
\hline H 19 & $\begin{array}{c}\text { Chestnut honey } \\
\text { Imeretia max }\end{array}$ & 26.50 & 6.28 & 5661.02 & 114.38 & 42.08 & 5850.26 & 0.59 & 1.96 & 0.30 \\
\hline H82 & $\begin{array}{c}\text { Chestnut honey } \\
\text { Adjara min }\end{array}$ & 52.82 & 45.50 & 5054.06 & 94.10 & 198.86 & 5445.34 & 0.54 & 1.42 & 0.38 \\
\hline H86 & $\begin{array}{c}\text { Chestnut honey } \\
\text { Adjara max }\end{array}$ & 108.68 & 197.80 & 7248.30 & 134.08 & 302.18 & 7991.04 & 0.80 & 1.93 & 0.41 \\
\hline H38 & $\begin{array}{l}\text { "Datunia"- Mix } \\
\text { Chestnut honey } \\
\text { commercial }\end{array}$ & 64.38 & 47.90 & 6879.26 & 92.30 & 503.22 & 7587.06 & 0.76 & 1.73 & 0.44 \\
\hline Source: Authors
\end{tabular}

\begin{tabular}{|c|c|c|c|c|c|c|}
\hline Name & Samplers & $\mathrm{Na}+$ & NH4+ & $\mathrm{K}+$ & $\mathrm{Mg} 2+$ & $\mathrm{Ca} 2+$ \\
\hline H 9 & $\begin{array}{l}\text { Chestnut honey } \\
\text { Mengrelia min }\end{array}$ & 1.64 & 1.03 & 95.66 & 1.42 & 0.25 \\
\hline Н 21 & $\begin{array}{l}\text { Chestnut honey } \\
\text { Mengrelia max }\end{array}$ & 1.01 & 0.70 & 93.29 & 1.05 & 3.95 \\
\hline H 18 & $\begin{array}{c}\text { Chestnut honey } \\
\text { Guria max }\end{array}$ & 1.99 & 0.93 & 91.31 & 1.03 & 4.74 \\
\hline H 17 & $\begin{array}{c}\text { Chestnut honey } \\
\text { Guria min }\end{array}$ & 1.51 & 0.99 & 91.90 & 1.48 & 4.13 \\
\hline Н 24 & $\begin{array}{l}\text { Chestnut honey } \\
\text { Imeretia min }\end{array}$ & 2.10 & 0.89 & 92.36 & 0.88 & 3.77 \\
\hline H 19 & $\begin{array}{l}\text { Chestnut honey } \\
\text { Imeretia max }\end{array}$ & 0.45 & 0.11 & 96.77 & 1.96 & 0.72 \\
\hline H82 & $\begin{array}{c}\text { Chestnut honey } \\
\text { Adjara min }\end{array}$ & 0.97 & 0.84 & 92.81 & 1.73 & 3.65 \\
\hline H86 & $\begin{array}{c}\text { Chestnut honey } \\
\text { Adjara max }\end{array}$ & 1.36 & 2.48 & 90.71 & 1.68 & 3.78 \\
\hline H38 & $\begin{array}{c}\text { "Datunia"- Mix } \\
\text { Chestnut honey } \\
\text { commercial }\end{array}$ & 0.85 & 0.63 & 90.67 & 1.22 & 6.63 \\
\hline
\end{tabular}




Table 3: Linden (Tilia), Acacia and Polyfloral honey Cations, Conductivity and Ratio
\begin{tabular}{|c|c|c|c|c|c|c|}
\hline Name & Samplers & Na+ & NH4+ & K+ & Mg2+ & Ca2+ \\
\hline H 8 & Tilia (Clion) Honey Adjaria min & 1.55 & 0.86 & 93.94 & 1.92 & 1.72 \\
\hline H70 & Tilia (Clion) Honey Adjaria max & 1.82 & 0.45 & 88.66 & 1.30 & 7.77 \\
\hline H81 & Chestnut and Tilia honeyAdjariamin & 2.36 & 0.00 & 90.97 & 1.03 & 5.64 \\
\hline H36 & Chestnut and Tilia honeyAdjaria max & 1.32 & 0.40 & 91.69 & 1.26 & 5.32 \\
\hline H78 & Acacia honeyAdjaria min & 1.13 & 0.34 & 88.90 & 1.19 & 8.44 \\
\hline H90 & Acacia honeyAdjaria max & 1.12 & 0.42 & 90.94 & 1.90 & 5.62 \\
\hline H51 & Spring honey Adjaria min & 1.36 & 0.24 & 89.85 & 2.27 & 6.28 \\
\hline H52 & Spring honey Adjaria max & 2.90 & 1.49 & 87.91 & 2.18 & 5.52 \\
\hline H63 & Autumn honey Adjaria min & 2.19 & 0.00 & 89.94 & 1.58 & 6.29 \\
\hline H60 & Autumn honey Adjaria max & 2.18 & 0.00 & 90.36 & 1.67 & 5.79 \\
\hline Source: Authors & & & & \\
\hline
\end{tabular}

\begin{tabular}{|c|c|c|c|c|c|c|c|c|c|c|}
\hline \multicolumn{2}{|c|}{ Table 4 Percent distribution of cations in Linden (Tilia), Acacia and Polyfloral honey } \\
\hline Name & Samplers & $\begin{array}{c}\mathrm{Na}+ \\
\mathrm{ppm}\end{array}$ & $\begin{array}{c}\mathrm{NH}+ \\
\mathrm{ppm}\end{array}$ & $\begin{array}{c}\mathrm{K}+ \\
\mathrm{ppm}\end{array}$ & $\begin{array}{c}\mathrm{Mg} 2+ \\
\mathrm{ppm}\end{array}$ & $\begin{array}{c}\mathrm{Ca}+ \\
\mathrm{ppm}\end{array}$ & $\begin{array}{c}\text { Total } \\
\text { ppm }\end{array}$ & $\begin{array}{c}\text { Total } \\
\text { ations } \%\end{array}$ & $\begin{array}{c}\text { Cond } \\
\text { s/cm }\end{array}$ & $\begin{array}{c}\text { Ratio } \\
\text { Cation } \\
\text { /conduct }\end{array}$ \\
\hline H 8 & $\begin{array}{c}\text { Tilia (Clion) Honey } \\
\text { Adjaria min }\end{array}$ & 39.32 & 21.86 & 2377.34 & 48.56 & 43.64 & 2530.72 & 0.25 & 0.81 & 0.31 \\
\hline H70 & $\begin{array}{c}\text { Tilia (Clion) Honey } \\
\text { Adjaria max }\end{array}$ & 56.42 & 13.84 & 2746.58 & 40.24 & 240.86 & 3097.94 & 0.31 & 1.33 & 0.23 \\
\hline H81 & $\begin{array}{c}\text { Chestnut and Tilia } \\
\text { honeyAdjariamin }\end{array}$ & 134.32 & 0.00 & 5167.94 & 58.34 & 320.24 & 5680.84 & 0.57 & 1.70 & 0.33 \\
\hline H36 & $\begin{array}{c}\text { Chestnut and Tilia } \\
\text { honeyAdjaria max }\end{array}$ & 94.16 & 28.66 & 6516.32 & 89.36 & 378.42 & 7106.92 & 0.71 & 1.75 & 0.41 \\
\hline H78 & $\begin{array}{c}\text { Acacia honey } \\
\text { Adjaria min }\end{array}$ & 28.20 & 8.58 & 2220.22 & 29.78 & 210.68 & 2497.46 & 0.25 & 0.91 & 0.27 \\
\hline H90 & $\begin{array}{c}\text { Acacia honey } \\
\text { Adjaria max }\end{array}$ & 42.26 & 16.06 & 3444.50 & 72.08 & 212.94 & 3787.84 & 0.38 & 1.05 & 0.36 \\
\hline H51 & $\begin{array}{c}\text { Spring honey } \\
\text { Adjaria min }\end{array}$ & 44.76 & 7.88 & 2961.72 & 74.78 & 207.00 & 3296.14 & 0.33 & 0.96 & 0.34 \\
\hline H52 & $\begin{array}{c}\text { Spring honey } \\
\text { Adjaria max }\end{array}$ & 118.78 & 60.76 & 3595.44 & 89.04 & 225.96 & 4089.98 & 0.41 & 1.71 & 0.24 \\
\hline H63 & $\begin{array}{c}\text { Autumn honey } \\
\text { Adjaria min }\end{array}$ & 93.98 & 0.00 & 3856.28 & 67.58 & 269.62 & 4287.46 & 0.43 & 1.43 & 0.30 \\
\hline H60 & $\begin{array}{c}\text { Autumn honey } \\
\text { Adjaria max }\end{array}$ & 122.80 & 0.00 & 5092.18 & 94.06 & 326.44 & 5635.48 & 0.56 & 1.87 & 0.30 \\
\hline Source: Auhors & & & & & & & \\
\hline
\end{tabular}

\section{Conclusion}

From the above data and analysis, we can conclude that the quantitative content of potassium is dominant in all types of honey of botanical origin collected in western Georgia. The potassium content in the cation total amounts of Chestnut, Tilia, Acacia and Polyfloral honey and the ratio of cations total amounts and conductivity represent one of the markers to determine the naturalness of honey.

\section{Acknowledgement}

The designated Project has been fulfilled by financial support of the Georgia National Science Foundation (Grant AP/96/13, Grant216816), Any idea in this publication is possessed by the author and may not represent the opinion of the Georgia National Science Foundation.

\section{References}

Bogdanov, S., Haldimann, M., Luginbuhl, W., \& Gallmann, P. (2007). Minerals in honey: environmental, geographical and botanical aspects. Journal of Agriculture \& Bee World, 46(4), 269-275.

Chudzinska, M., \& Baralkiewicz, D. (2010). Estimation of honey authenticity by multi elements characteristics using inductively coupled plasma-mass spectrometry (ICP-MS) combined with chemometrics. Food \& Chemical Toxicology, 48 (1), 284-290. 
Conti, M. E., Finoia, M. G., Fontana, L., Mele, G., Botrè, F., \& Iavicoli, I. (2014). Characterization of Argentine honeys on the basis of their mineral content and some typical quality parameters. Chemistry Central Journal, 8, 44.

Conti, M. E., Stripeikis, J., Campanella, L., Cucina, D., \& Tudino, M. B. (2007). Characterization of Italian honeys (Marche Region) on the basis of their mineral content and some typical quality parameters. Chemistry Central Journal, $1,14$.

González-Miret, M.L., Terrab, A., Hernanz, D., Fernández-Recamales, M. A., \& Heredia, F. J. (2005). Multivariate Correlation between Color and Mineral Composition of Honeys and by Their Botanical Origin. Journal of Agriculture and Food Chemistry, 53 (7), 2574-2580.

Fernández-Torres, R., Pérez-Bernal, J.L., Bello-López, M.A., Callejón-Mochón, M., Jiménez-Sánchez, J.C., \& GuiraúmPérez, A. (2005). Mineral content and botanical origin of Spanish honeys. Talanta, 65 (3), 686-696.

Moniruzzaman, M., Chowdhury, M.A., Rahman, M.A., Sulaiman, S.A., \& Gan, S.H. (2014). Determination of Mineral, Trace Element, and Pesticide Levels in Honey Samples Originating from Different Regions of Malaysia Compared to Manuka Honey. BioMed research international.

Uršulin-Trstenjak, N., Puntarić, D., Levanić, D., Gvozdić, V., Pavlek, Z., Puntarić, A., Puntarić, E., Puntarić, I.,Vidosavljević, D., Dario Lasić, D., \& Vidosavljević, M. (2017). Physicochemical, and Mineral Analysis of Croatian Acacia Honey Samples: Applicability for Identification of Botanical and Geographical Origin. Journal of Food Quality, Retrieved from https://doi.org/10.1155/2017/8538693

Terrab, A., Hernanz, D., \& Heredia, F.J. (2004).Inductively coupled plasma optical emission spectrometric determination of minerals in thyme honeys and their contribution to geographical discrimination. Journal of Agriculture and Food Chemistry, . 52 (11), 3441-3445.

Vanhanen L.P,.Emmertz A. \& Savage G.P.,(2011).Mineral analysis of mono-floral New Zealand honey.Food Chemistry,128 (1), 236-240.

Wieczorek, J., Pietrzak, M., Pomianowski, J., Wieczorek, Z. (2014). Honey as a source of bioactive compounds. Polish Journal of Environmental studies, 29 (3), 275-285.

Yücel, Y., \& Sultanoğlu, P.(2013). Characterization of Hatay honey saccordingtotheirmulti-element analysis using ICP-OES combined with chemometrics. Food Chemistry, 140 (1-2), 231-237. 